\title{
Analysis of diagnostic informative value of the Full Outline of UnResponsiveness Scale in patients with spontaneous supratentorial intracerebral hemorrhage
}

\author{
A. A. Kuznietsov \\ Zaporizhzhia State Medical University, Ukraine
}

The main purpose of the study was to verify the diagnostic informative value of the Full Outline of UnResponsiveness Scale in patients with $\mathrm{SSICH}$ based on the comparison with neuroimaging criteria of midline shift severity.

Material and methods. Prospective cohort study of 138 patients in acute period of SSICH was conducted, which included clinical assessment (using the Full Outline of UnResponsiveness (FOUR) Scale and the Glasgow Coma Scale (GCS) scores) and neuroimaging estimation of cerebral injury severity. A comparative analysis of Spearman's rank correlation coefficients $(R)$ and different areas under the receiver operating characteristic curves (derived from the same cases) was conducted with the help of $Z$ statistic.

Results. The Full Outline of UnResponsiveness Scale was verified as a highly informative tool for the presence and severity of midline shift clinical detection (AUC $>0.80, \mathrm{P}<0.0001$ ) in patients with $\mathrm{SSICH}$, whereas the diagnostic informative value of the FOUR scale within the assessment of severe midline shift clinical signs was higher than that for mild midline shift detection (AUC $=0.97 \pm 0.02$ versus AUC $=0.84 \pm 0.05$ for septum pellucidum displacement, $P=0.0158$; $A U C=0.99 \pm 0.01$ versus AUC $=0.92 \pm 0.03$ for pineal gland displacement, $P=0.0269$ ). The Full Outline of UnResponsiveness Scale had a higher diagnostic informative value than the GCS as for the presence of midline shift clinical signs detection (AUC $=0.81 \pm 0.03$ versus AUC $=0.67 \pm 0.04, P=0.0002$; accuracy $77.5 \%$ versus $63.0 \%, P=0.0085$ ), as well as for the clinical assessment of septum pellucidum displacement severity (AUC $=0.80 \pm 0.04$ versus $A U C=0.73 \pm 0.05, P=0.0286$ ) and pineal gland displacement (AUC $=0.80 \pm 0.05$ versus AUC $=0.74 \pm 0.05, P=0.0306$ ) in patients with midline shift $<4 \mathrm{~mm}$ due to SSICH.

Conclusions. The Full Outline of UnResponsiveness Scale is characterized by the higher diagnostic informative value in clinical detecting midline shift severity in patients with $\mathrm{SSICH}$.

\section{Аналіз діагностичної інформативності шкали Full Outline of UnResponsiveness у пацієнтів зі спонтанним супратенторіальним внутрішньомозковим крововияивом}

\section{А. А. Кузнєцов}

Мета роботи - аналіз діагностичної інформативності шкали Full Outline of UnResponsiveness (FOUR) у пацієнтів зі спонтанним супратенторіальним внутрішньомозковим крововиливом (ССВМК) на підставі зіставлення з нейровізуалізаційними критеріями оцінювання тяжкості латеральної дислокації серединних структур мозку.

Матеріали та методи. Виконали проспективне, когортне дослідження 138 пацієнтів у гострому періоді ССВМК, що включало комплексне клініко-неврологічне дослідження (з використанням шкали FOUR i шкали коми Глазго (ШКГ)), а також нейровізуалізаційне оцінювання тяжкості ушкодження церебральних структур у дебюті захворювання. Порівняльний аналіз коефіцієнтів рангової кореляції Спірмена та площі під ROC-кривими виконали з використанням Z statistic.

Результати. Встановили, що шкала FOUR є високоінформативним інструментом клінічної детекції наявності та вираженості латеральної дислокації серединних структур мозку (AUC > 0,80, p < 0,0001) у пацієнтів із ССВМК, діагностична інформативність шкали FOUR в оцінюванні клінічних проявів тяжкої дислокації середніх структур мозку вище за таку для детекції зсуву легкого ступеня $(A \cup C=0,97 \pm 0,02$ проти $A U C=0,84 \pm 0,05$ для зсуву прозорої перетинки, $p=0,0158 ; A U C=0,99 \pm 0,01$ проти AUC $=0,92 \pm 0,03$ для зсуву епіфіза, $p=0,0269)$. Шкала FOUR перевищувала ШКГ за діагностичною інформативністю в детекції наявності клінічних проявів дислокаційного синдрому ( $\mathrm{UUC}=0,81 \pm 0,03$ проти $\mathrm{AUC}=0,67 \pm 0,04, p=0,0002$; точність $77,5 \%$ проти $63,0 \%, p=0,0085$ ), а також у клінічному оцінюванні вираженості дислокації прозорої перетинки $(A \cup C=0,80 \pm 0,04$ проти $A U C=0,73 \pm 0,05, p=0,0286$ ) й епіфіза ( $A U C=0,80 \pm 0,05$ проти $A U C=0,74 \pm 0,05, p=0,0306$ ) у пацієнтів зі зсувом <4 мм внаслідок ССВМК.

Висновки. Шкала FOUR характеризується більшою діагностичною інформативністю у клінічній детекції вираженості дислокаційного синдрому в пацієнтів із ССВМК.

\section{Анализ диагностической информативности шкалы Full Outline of UnResponsiveness у пациентов со спонтанным супратенториальным внутримозговым кровоизлиянием}

\section{А. А. Кузнецов}

Цель работы - анализ диагностической информативности шкалы Full Outline of UnResponsiveness (FOUR) у пациентов со спонтанным супратенториальным внутримозговым кровоизлиянием (ССВМК) на основании сопоставления с нейровизуализационными критериями оценки тяжести латеральной дислокации срединных структур мозга.

Материалы и методы. Проведено проспективное, когортное исследование 138 пациентов в остром периоде ССВМК, которое включало комплексное клинико-неврологическое исследование (с использованием шкалы FOUR и шкалы комы
Key words: hemorrhage, neurological diagnostic technic.

Zaporozhye medical journal 2019; 21 (1), 33-38

Dol: 10.14739/2310-1210 2019.1.155799

E-mail: titus3.05@gmail.com
Киючові слова: крововилив, неврологічні Аіагностичні метоАи.

Запорізький медичний журнал. - 2019. T. 21, № 1(112), C. 33-38
Киючевые слова: кровоизлияние, неврологические Аиагностические методы.

\section{Запорожский} медицинский журнал. - 2019. T. 21, № 1(112). C. 33-38 
Глазго (ШКГ)), а также нейровизуализационную оценку тяжести повреждения церебральных структур в дебюте заболевания. Сравнительный анализ коэффрициентов ранговой корреляции Спирмена и площади под ROC-кривыми проводили с использованием Z statistic.

Результаты. Установлено, что шкала FOUR - высокоинформативный инструмент клинической детекции наличия и выраженности латеральной дислокации срединных структур мозга (AUC > 0,80, p < 0,0001) у пациентов со ССВМК, диагностическая информативность шкалы FOUR в оценке клинических проявлений тяжелой дислокации срединных структур мозга выше таковой для детекции смещения легкой степени (AUC $=0,97 \pm 0,02$ против $A U C=0,84 \pm 0,05$ для смещения прозрачной перегородки, $p=0,0158 ; A U C=0,99 \pm 0,01$ против AUC $=0,92 \pm 0,03$ для смещения эпифиза, $p=0,0269)$. Шкала FOUR превосходила ШКГ по диагностической информативности в детекции наличия клинических проявлений дислокационного синдрома ( $\mathrm{AUC}=0,81 \pm 0,03$ против $\mathrm{AUC}=0,67 \pm 0,04, \mathrm{p}=0,0002$; точность $77,5 \%$ против 63,0 \%, $\mathrm{p}=0,0085$ ), а также в клинической оценке выраженности дислокации прозрачной перегородки (AUC $=0,80 \pm 0,04$ против AUC $=0,73 \pm 0,05, p=0,0286$ ) и эпифиза (AUC = 0,80 $\pm 0,05$ против AUC $=0,74 \pm 0,05, p=0,0306$ ) у пациентов со смещением <4 мм вследствие ССВМК.

Выводы. Шкала FOUR характеризуется более высокой диагностической информативностью в клинической детекции выраженности дислокационного синдрома у пациентов со ССВМК.

Spontaneous supratentorial intracerebral hemorrhage (SSICH) is the leading cause of death and disability of young and middle aged people in most countries of the world [3].

The significant role of intracerebral hematoma volume effect along with the perifocal edema in progressive midline shift development and precondition for unfavorable course and outcome of SSICH acute period has been convincingly proved [12].

The Glasgow Coma Scale (GCS) and the National Institutes of Health Stroke Scale are the most common to quantify the severity of cerebral and focal syndromes [2]. In spite of the fact that the Glasgow Coma Scale is the gold standard for assessing the level of consciousness in clinical angioneurology, its significance for the determination of midline shift severity in patients with cerebral hemorrhagic supratentorial stroke has recently been challenged. The presence of aphasic disorders in patients with dominant hemisphere damage reduces the informative and prognostic value of the Glasgow Coma Scale in the acute period of the disease. In addition, the Glasgow Coma Scale does not include some important signs of the brainstem functional activity evaluation, namely: respiratory pattern, pupillary reactions, as well as corneal, conjunctival and pharyngeal reflexes [15]. All of the above justifies the expediency of more informative clinical scales research for the objectification of midline shift severity and the further determination of vital and functional outcome prognosis in the acute period of the disease.

Taking all of this into account, we pay our particular attention to the Full Outline of UnResponsiveness Scale, which includes the assessment of eye movements, respiratory pattern, motor reactions, brainstem reflexes and motor reactions. The evaluation of each function consists of 5 gradations $(0-4)[1,16]$. This scale does not take into consideration verbal reactions, which excludes the lateralization of lesion influence on the total score [2]. The abovementioned suggests the prospective viability of the Full Outline of UnResponsiveness Scale use in patients with $\mathrm{SSICH}$, however, the information as for the diagnostic informative value of this scale in the acute period of the disease are absent, which justifies the viability of the further studies in this area.

\section{The aim}

The aim of the study was the analysis of the diagnostic informative value of the Full Outline of UnResponsiveness Scale in patients with $\mathrm{SSICH}$ based on the comparison with neuroimaging criteria of midline shift severity.

\section{Materials and methods}

In order to achieve this goal, a comparative study was conducted on 138 patients ( 79 men and 59 women, mean age $63.6 \pm 1.0$ years), who underwent a therapy in the Brain Circulation Disorders Department of the Municipal Institution "Zaporizhzhia City Clinical Hospital \# 6".

Inclusion criteria:

1) men and women with $\mathrm{SSICH}$ confirmed by the results of clinical and neuroimaging study;

2) admission to the hospital within the first 24 hours of the disease onset;

3) informed consent signed by the patient for study participation.

Exclusion criteria:

1) $\geq 2$ lesions;

2) combined stroke;

3) acute brain circulation disorders in the past medical history;

4) decompensated somatic pathology;

5) oncopathology.

The diagnosis of SSICH was confirmed based on the results of neuroimaging study, which was conducted on admission to hospital using a computed tomography scanner "Siemens Somatom Spirit" (Germany). Lesion size and midline shift severity were considered.

Clinical and neurological study included the assessment of neurological deficit severity on the National Institute of Health Stroke Scale (NIHSS). The Glasgow Coma Scale (GCS) and the Full Outline of UnResponsiveness Scale (FOUR) were used in order to assess the severity of dislocation syndrome clinical signs.

Statistical analysis of the obtained data was carried out with the help of Statisticfa for Windows 13 (StatSoft Inc., № JPZ804I382130ARCN10-J) and MedCalc (version 16.4). The distribution normality of the studied traits was assessed by Shapiro-Wilk criterion. Since the majority of indicators distribution did not comply with the laws of normality, descriptive statistics were presented in the form of the median (Me) and interquartile range $\left(Q_{25}-Q_{75}\right)$. Spearman's rank correlation coefficient $(R)$ was used for the interrelation between quantitative characteristics assessment. The diagnostic criteria were determined by the ROC analysis. The optimal cut-off values were estimated with the help of Youden index method. A comparative analysis of correlation coefficients and different areas under the receiver operating curves (derived from the same cases) was conducted 
with the help of $Z$ statistic. Chi-squared test was used for the intergroup differences of diagnostic criteria accuracy assessment. $P<0.05$ was considered to indicate a statistically significant difference.

\section{Results}

Baseline NIHSS score in the cohort was $12(7 ; 18)$, FOUR score and GCS score - $16(14 ; 16)$ and $14(11 ; 15)$, respectively.

Midline shift was verified in $78(56.5 \%)$ cases using neuroimaging studies. The results of the septum pellucidum and pineal gland displacement severity assessment in patients are presented in Table 1.

Mild septum pellucidum displacement $(1-5 \mathrm{~mm})$ was detected in $50(36.3 \%)$ patients, moderate $(6-10 \mathrm{~mm})$ and severe (>10 mm) - in 18(13.0) and $10(7.2 \%)$ patients, respectively. Mild pineal gland displacement $(1-5 \mathrm{~mm})$ was detected in $44(42.4 \%)$ patients, moderate $(6-10 \mathrm{~mm})$ and severe $(>10 \mathrm{~mm})$ - in $11(8.0 \%)$ and 7 (5.1\%) cases, respectively.

The analysis results of the informative value of the FOUR Scale within the clinical assessment of septum pellucidum displacement severity in comparison with the GCS are presented in Table 2.
As the data shows, the AUC value when using the FOUR Scale as the tool for the verification of clinical signs of severe septum pellucidum displacement $(>10 \mathrm{~mm})$ constituted $0.97 \pm 0.02(\mathrm{P}<0.0001)$, which exceeded the values of FOUR Scale for the clinical detection of mild septum pellucidum displacement $(1-5 \mathrm{~mm}$ ) (AUC $=0.84 \pm 0.05, P=0.0158)$. AUC values were also high when FOUR Scale was used for the verification of the clinical signs of severe pineal gland displacement as well as those of mild pineal gland displacement. They constituted $0.99 \pm 0.01(P<0.0001)$ and $0.92 \pm 0.03(P<0.0001)$ respectively (Table 3).

It was determined that the FOUR Scale was statistically more significant than the GCS as for the diagnostic informative value when used as a tool for the clinical detection of midline shift ( $A \cup C=0.81 \pm 0.03$ versus $A U C=0.67 \pm 0.04, P=0.0002$ ), as well as for the severity assessment of the septum pellucidum displacement $<4 \mathrm{~mm}(\mathrm{AUC}=0.80 \pm 0.04$ versus $\mathrm{AUC}=0.73 \pm 0.05$, $\mathrm{P}=0.0286)$ and pineal gland displacement $<4 \mathrm{~mm}$ ( $A \cup C=0.80 \pm 0.05$ versus $A \cup C=0.74 \pm 0.05, P=0.0306$ ). However, the aforementioned scales were compared on the basis of the discriminate potential of the midline shift $>5 \mathrm{~mm}$ and $>10 \mathrm{~mm}$ clinical signs detection.

Table 1. The structure of the dislocation syndrome severity in patients

\begin{tabular}{|c|c|c|}
\hline Midline shift & Septum pellucidum displacement, $\mathrm{n}(\%)$ & Pineal gland displacement, $\mathrm{n}(\%)$ \\
\hline absent & $60(43.5)$ & $60(43.5)$ \\
\hline $1 \mathrm{~mm}$ & $7(5.1)$ & $7(5.1)$ \\
\hline $2 \mathrm{~mm}$ & $13(9.4)$ & $18(13.0)$ \\
\hline $3 \mathrm{~mm}$ & $15(10.9)$ & $19(13.8)$ \\
\hline $4 \mathrm{~mm}$ & $8(5.8)$ & $12(8.7)$ \\
\hline $5 \mathrm{~mm}$ & $7(5.1)$ & $4(2.9)$ \\
\hline $6-10 \mathrm{~mm}$ & $18(13.0)$ & $11(8.0)$ \\
\hline$>10 \mathrm{~mm}$ & $10(7.2)$ & $7(5.1)$ \\
\hline
\end{tabular}

Table 2. Comparative analysis of the informative value of the Full Outline of UnResponsiveness Scale and Glasgow Coma Scale within the clinical assessment of septum pellucidum displacement severity in patients with SSICH

\begin{tabular}{|c|c|c|c|c|c|c|}
\hline \multirow{2}{*}{$\begin{array}{l}\text { Septum pellucidum } \\
\text { displacement }\end{array}$} & \multicolumn{2}{|c|}{ Full Outline of UnResponsiveness Scale } & \multicolumn{2}{|c|}{ Glasgow Coma Scale } & \multirow[t]{2}{*}{ Z statistic } & \multirow[t]{2}{*}{$\mathbf{P}$} \\
\hline & AUC \pm SE & $\mathbf{P}$ & AUC $\pm S E$ & $\mathbf{P}$ & & \\
\hline$>0 \mathrm{~mm}$ & $0.81 \pm 0.03$ & $<0.0001$ & $0.67 \pm 0.04$ & 0.0001 & 3.68 & 0.0002 \\
\hline$>1 \mathrm{~mm}$ & $0.80 \pm 0.03$ & $<0.0001$ & $0.66 \pm 0.04$ & 0.0003 & 3.92 & 0.0001 \\
\hline$>2 \mathrm{~mm}$ & $0.76 \pm 0.04$ & $<0.0001$ & $0.67 \pm 0.05$ & 0.0003 & 2.50 & 0.0125 \\
\hline$>3 \mathrm{~mm}$ & $0.80 \pm 0.04$ & $<0.0001$ & $0.73 \pm 0.05$ & $<0.0001$ & 2.20 & 0.0286 \\
\hline$>4 \mathrm{~mm}$ & $0.85 \pm 0.04$ & $<0.0001$ & $0.80 \pm 0.04$ & $<0.0001$ & 1.36 & 0.1730 \\
\hline$>5 \mathrm{~mm}$ & $0.84 \pm 0.05$ & $<0.0001$ & $0.82 \pm 0.05$ & $<0.0001$ & 0.61 & 0.5419 \\
\hline$>10 \mathrm{~mm}$ & $0.97 \pm 0.02$ & $<0.0001$ & $0.96 \pm 0.02$ & $<0.0001$ & 0.90 & 0.3669 \\
\hline
\end{tabular}

Table 3. Comparative analysis of the informative value of Full Outline of UnResponsiveness Scale and Glasgow Coma Scale within the assessment of pineal gland displacement severity in patients with $\mathrm{SSICH}$

\begin{tabular}{|c|c|c|c|c|c|c|}
\hline \multirow[t]{2}{*}{ Pineal gland displacement } & \multicolumn{2}{|c|}{ Full Outline of UnResponsiveness Scale } & \multicolumn{2}{|c|}{ Glasgow Coma Scale } & \multirow[t]{2}{*}{ z statistic } & \multirow[t]{2}{*}{$\mathbf{P}$} \\
\hline & AUC \pm SE & $\mathbf{P}$ & AUC \pm SE & $\mathbf{P}$ & & \\
\hline$>0 \mathrm{~mm}$ & $0.81 \pm 0.03$ & $<0.0001$ & $0.67 \pm 0.04$ & $<0.0001$ & 3.68 & 0.0002 \\
\hline$>1 \mathrm{~mm}$ & $0.80 \pm 0.04$ & $<0.0001$ & $0.71 \pm 0.04$ & $<0.0001$ & 2.59 & 0.0096 \\
\hline$>2 \mathrm{~mm}$ & $0.78 \pm 0.04$ & $<0.0001$ & $0.74 \pm 0.04$ & $<0.0001$ & 1.26 & 0.2069 \\
\hline$>3 \mathrm{~mm}$ & $0.80 \pm 0.05$ & $<0.0001$ & $0.74 \pm 0.05$ & $<0.0001$ & 2.16 & 0.0306 \\
\hline$>4 \mathrm{~mm}$ & $0.90 \pm 0.04$ & $<0.0001$ & $0.88 \pm 0.04$ & $<0.0001$ & 1.10 & 0.2709 \\
\hline$>5 \mathrm{~mm}$ & $0.92 \pm 0.03$ & $<0.0001$ & $0.91 \pm 0.04$ & $<0.0001$ & 0.64 & 0.5251 \\
\hline$>10 \mathrm{~mm}$ & $0.99 \pm 0.01$ & $<0.0001$ & $0.97 \pm 0.01$ & $<0.0001$ & 0.33 & 0.7383 \\
\hline
\end{tabular}


Table 4. Optimal cut-off values of the FOUR score and GCS score for the clinical assessment of the septum pellucidum displacement severity

\begin{tabular}{|c|c|c|c|c|c|c|}
\hline \multirow{2}{*}{$\begin{array}{l}\text { Septum pellucidum } \\
\text { displacement }\end{array}$} & \multicolumn{3}{|c|}{ Full Outline of UnResponsiveness Scale score } & \multicolumn{3}{|c|}{ Glasgow Coma Scale score } \\
\hline & Cut-off value & Se & Sp & Cut-off value & Se & Sp \\
\hline$>0 \mathrm{~mm}$ & $\leq 15$ & $73.1 \%$ & $83.3 \%$ & $\leq 14$ & $71.8 \%$ & $51.7 \%$ \\
\hline$>1 \mathrm{~mm}$ & $\leq 15$ & $74.6 \%$ & $79.1 \%$ & $\leq 14$ & $71.8 \%$ & $49.3 \%$ \\
\hline$>2 \mathrm{~mm}$ & $\leq 15$ & $72.4 \%$ & $68.8 \%$ & $\leq 14$ & $72.4 \%$ & $46.3 \%$ \\
\hline$>3 \mathrm{~mm}$ & $\leq 15$ & $81.4 \%$ & $66.3 \%$ & $\leq 12$ & $58.1 \%$ & $73.7 \%$ \\
\hline$>4 \mathrm{~mm}$ & $\leq 14$ & $71.4 \%$ & $82.5 \%$ & $\leq 11$ & $65.7 \%$ & $77.7 \%$ \\
\hline$>5 \mathrm{~mm}$ & $\leq 14$ & $78.6 \%$ & $80.9 \%$ & $\leq 11$ & $71.4 \%$ & $76.4 \%$ \\
\hline$>10 \mathrm{~mm}$ & $\leq 12$ & $90.0 \%$ & $90.2 \%$ & $\leq 10$ & $90.0 \%$ & $86.7 \%$ \\
\hline
\end{tabular}

Table 5. Optimal cut-off values of the FOUR score and GCS score for the clinical assessment of the pineal gland displacement severity

\begin{tabular}{|c|c|c|c|c|c|c|}
\hline \multirow[t]{2}{*}{ Pineal gland displacement } & \multicolumn{3}{|c|}{ Full Outline of UnResponsiveness Scale score } & \multicolumn{3}{|c|}{ Glasgow Coma Scale score } \\
\hline & Cut-off value & Se & Sp & Cut-off value & Se & Sp \\
\hline$>0 \mathrm{~mm}$ & $\leq 15$ & $73.1 \%$ & $83.3 \%$ & $\leq 14$ & $71.8 \%$ & $51.7 \%$ \\
\hline$>1 \mathrm{~mm}$ & $\leq 15$ & $74.6 \%$ & $79.1 \%$ & $\leq 14$ & $77.5 \%$ & $55.2 \%$ \\
\hline$>2 \mathrm{~mm}$ & $\leq 15$ & $77.4 \%$ & $64.9 \%$ & $\leq 14$ & $83.0 \%$ & $51.8 \%$ \\
\hline$>3 \mathrm{~mm}$ & $\leq 14$ & $67.6 \%$ & $80.8 \%$ & $\leq 12$ & $61.8 \%$ & $72.1 \%$ \\
\hline$>4 \mathrm{~mm}$ & $\leq 13$ & $68.2 \%$ & $93.1 \%$ & $\leq 12$ & $86.4 \%$ & $73.3 \%$ \\
\hline$>5 \mathrm{~mm}$ & $\leq 13$ & $72.2 \%$ & $91.7 \%$ & $\leq 11$ & $88.9 \%$ & $75.0 \%$ \\
\hline$>10 \mathrm{~mm}$ & $\leq 10$ & $100.0 \%$ & $96.2 \%$ & $\leq 8$ & $100.0 \%$ & $93.1 \%$ \\
\hline
\end{tabular}

Table 6. Comparative analysis of the diagnostic accuracy of the Full Outline of UnResponsiveness Scale score and Glasgow Coma Scale score when used as the criteria for the clinical assessment of the septum pellucidum displacement severity

\begin{tabular}{|c|c|c|c|c|}
\hline Septum pellucidum displacement & Full Outline of UnResponsiveness Scale & Glasgow Coma Scale & Chi-squared & $\mathbf{P}$ \\
\hline$>0 \mathrm{~mm}$ & $77.5 \%$ & $63.0 \%$ & 6.92 & 0.0085 \\
\hline$>1 \mathrm{~mm}$ & $76.8 \%$ & $60.9 \%$ & 8.85 & 0.0029 \\
\hline$>2 \mathrm{~mm}$ & $70.3 \%$ & $58.0 \%$ & 4.54 & 0.0332 \\
\hline$>3 \mathrm{~mm}$ & $76.8 \%$ & $68.8 \%$ & 2.21 & 0.1374 \\
\hline$>4 \mathrm{~mm}$ & $82.6 \%$ & $81.2 \%$ & 0.10 & 0.7550 \\
\hline$>5 \mathrm{~mm}$ & $86.7 \%$ & $79.7 \%$ & 2.60 & 0.1069 \\
\hline$>10 \mathrm{~mm}$ & $95.7 \%$ & $95.7 \%$ & 0.00 & 1.0000 \\
\hline
\end{tabular}

Table 7. Comparative analysis of the diagnostic accuracy of the Full Outline of UnResponsiveness Scale score and Glasgow Coma Scale score when used as the criteria for the clinical assessment of the pineal gland displacement severity

\begin{tabular}{|c|c|c|c|c|}
\hline Pineal gland displacement & Full Outline of UnResponsiveness Scale & Glasgow Coma Scale & Chi-squared & $\mathbf{P}$ \\
\hline$>0 \mathrm{~mm}$ & $77.5 \%$ & $63.0 \%$ & 6.92 & 0.0085 \\
\hline$>1 \mathrm{~mm}$ & $76.8 \%$ & $64.5 \%$ & 5.03 & 0.0249 \\
\hline$>2 \mathrm{~mm}$ & $74.6 \%$ & $68.8 \%$ & 1.14 & 0.2857 \\
\hline$>3 \mathrm{~mm}$ & $76.8 \%$ & $75.4 \%$ & 0.78 & 0.3762 \\
\hline$>4 \mathrm{~mm}$ & $91.3 \%$ & $90.0 \%$ & 0.17 & 0.6808 \\
\hline$>5 \mathrm{~mm}$ & $94.2 \%$ & $91.3 \%$ & 0.86 & 0.3539 \\
\hline$>10 \mathrm{~mm}$ & $96.4 \%$ & $94.9 \%$ & 0.08 & 0.7767 \\
\hline
\end{tabular}

Optimal cut-off values of the FOUR score and GCS score were determined based on a ROC analysis. They serve as clinical criteria of the midline shift presence, as well as criteria for the clinical assessment of septum pellucidum and pineal gland displacement severity (Tables 4 and 5).

Thus, FOUR score $>14$ is a clinical diagnostic criterion for mild septum pellucidum displacement $(<6 \mathrm{~mm})$ or the $a b$ sence of displacement ( $\mathrm{Se}=80.9 \%$; $\mathrm{Sp}=78.6 \%)$; FOUR score $>13$ is associated with mild pineal gland displacement $(<6 \mathrm{~mm})$ or the absence of displacement $(\mathrm{Se}=91.7 \%$; $\mathrm{Sp}=72.2 \%$ ); FOUR score $<12$ is a clinical diagnostic criterion for severe septum pellucidum displacement ( $>10 \mathrm{~mm})$ $(\mathrm{Se}=90.0 \%$; Sp $=90.2 \%)$; FOUR score $<10$ is asso- ciated with severe pineal gland displacement $(>10 \mathrm{~mm})$ (Se $=100.0 \%$; Sp $=96.2 \%$ ).

The analysis results of the diagnostic accuracy of the FOUR Scale score when used as the criteria for the clinical assessment of midline shift severity are presented in Tables 6 and 7.

As the presented data show, the FOUR Scale has a high accuracy when used as the assessment tool for the severity of septum pellucidum (86.7-95.7\%) and pineal gland displacement (94.2-96.4\%) clinical signs. The FOUR Scale was as accurate as the GCS when used for the clinical signs of moderate and severe midline shift assessment. However, the FOUR Scale was more accurate than the Glasgow Coma Scale as for the clinical signs of midline shift detection 
( $77.5 \%$ versus $63.0 \%$, Chi-squared $=6.92, P=0.0085)$, as well as for the accurate clinical assessment of the severity of septum pellucidum displacement up to $3 \mathrm{~mm}(70.3 \%$ versus $58.0 \%$, Chi-squared $=4.54, \mathrm{P}=0.0332$ ) and pineal gland displacement up to $2 \mathrm{~mm}(76.8 \%$ versus $64.5 \%$, Chi-squared $=5.03, P=0.0249$ ).

Based on a correlation analysis along with the calculation of Spearman's rank correlation coefficients (R) it was determined that the FOUR score was statistically more associated with septum pellucidum displacement ( $\mathrm{R} 95 \% \mathrm{Cl}=-0.65(-0.54 ;-0.74), \mathrm{P}<0.0001$ versus -0.42 $(-0.27 ;-0.54), P<0.0001$ for GCS score, $Z$ statistic $=-2.69$, $P=0.0071)$ and pineal gland displacement $(R 95 \%$ $\mathrm{Cl}=-0.65(-0.54 ;-0.71), \mathrm{P}<0.0001$ versus $-0.45(-0.31$; $-0.57), P<0.0001$ for the GCS score, $Z$ statistic $=-2.39$, $P=0.017)$.

\section{Discussion}

It was determined that AUC values for the FOUR Scale corresponded to "very high" and "excellent" gradations in accordance with the International Expert Scale of binary classification quality assessment M. H. Zweig, G. Campbell (1993) [17]. The obtained results showed a high diagnostic informative value of the FOUR Scale for the clinical signs of midline shift detection in patients with SSICH in the acute period, furthermore the AUC value was the highest when the FOUR Scale was used as a tool for the verification of clinical signs of severe septum pellucidum displacement $(0.97 \pm 0.02$ versus $0.84 \pm 0.05, P=0.0158)$ and severe pineal gland displacement $(0.99 \pm 0.01$ versus $0.92 \pm 0.03$, $P=0.0269$ ). Based on the ROC analysis optimal cut-off values of the FOUR Scale score were determined for the clinical assessment of midline shift severity.

The FOUR Scale has a statistically higher diagnostic informative value than the GCS when used as a tool for the clinical detection of midline shift (AUC $=0.81 \pm 0.03$ versus $A U C=0.67 \pm 0.04, P=0.0002$; accuracy $77.5 \%$ versus $63.0 \%$, Chi-squared $=6.92, P=0.0085$ ), as well as for the severity assessment of the septum pellucidum displacement $<4 \mathrm{~mm}$ (AUC $=0.80 \pm 0.04$ versus $A U C=0.73 \pm 0.05, P=0.0286)$ and pineal gland displacement $<4 \mathrm{~mm}(A \cup C=0.80 \pm 0.05$ versus $A U C=0.74 \pm 0.05$, $P=0.0306)$.

The obtained data are consistent with the results of other studies, which showed, that the FOUR Scale was superior to the GCS in detecting risk of lethal outcome in critically ill patients [14] with acute ischemic stroke [9] and traumatic brain injury $[8,11]$.

The FOUR Scale showed a higher diagnostic informative value than the GCS within the results of the comparative analysis of the correlation coefficient between the values of these scales and the midline shift severity ( $R 95 \%$ $\mathrm{Cl}=-0.65(-0.54 ;-0.74)$ versus $-0.42(-0.27 ;-0.54)$ for the pairs of indexes of the "FOUR Scale score - septum pellucidum displacement" and the "GCS score - septum pellucidum displacement", respectively, $\mathrm{P}=0.0071$ ) and pineal gland displacement $(\mathrm{R} 95 \% \mathrm{Cl}=-0.65(-0.54$; $-0.71)$ versus $-0.45(-0.31 ;-0.57)$ for the pairs of indexes of the "FOUR Scale score - pineal gland displacement" and the "GCS score - pineal gland displacement", respectively, $P=0.017)$.
In our opinion, a higher diagnostic informative value of the FOUR Scale in comparison with the GCS was due, on the one hand, to the fact that the verbal reaction assessment in the structure of the FOUR Scale was absent, and the latter was influenced by the lateralization of the lesion in patients with supratentorial intracerebral hemorrhage. On the other hand, the spectrum of the assessed indexes had some additional criteria for the clinical assessment of the supratentorial structures functional state (respiratory pattern, brainstem reflexes). The study of $Y$. Hu et al. (2017) showed, that motor response and brainstem responses were verified as independent predictors of conscious awareness recovery in patients with acute ischemic stroke [7]. By the results of M. A. Gorji et al. (2015), the FOUR score was more accurate and practical in intubated patients regarding a lack of verbal response factor in early prediction of mortality in the GCS [6].

All of the above together with numerous studies convincingly proving a high inter-rater agreement of the FOUR Scale using $[4,5,10,13,16]$ makes this scale more useful and preferable than the GCS for the assessment of midline shift clinical signs severity in patients in the acute period of SSICH.

\section{Conclusions}

1. The FOUR Scale is a highly informative tool for the clinical detection of midline shift presence and severity (AUC > 0.80, $\mathrm{P}<0.0001$ ) in patients with $\mathrm{SSICH}$, whereas the diagnostic informative value of this scale within the assessment of severe midline shift clinical signs is higher than for the detection of mild midline shift (AUC $=0.97 \pm 0.02$ versus $A U C=0.84 \pm 0.05$ for septum pellucidum displacement, $P=0.0158 ; A U C=0.99 \pm 0.01$ versus $A U C=0.92 \pm 0.03$ for pineal gland displacement, $P=0.0269$ ).

2. The FOUR Scale has a higher diagnostic informative value than the GCS as for the detection of midline shift clinical signs presence (AUC $=0.81 \pm 0.03$ versus AUC $=0.67 \pm 0.04, P=0.0002$; accuracy $77.5 \%$ versus $63.0 \%$, Chi-squared test $P=0.0085$ ), as well as for the clinical assessment of septum pellucidum displacement ( $A \cup C=0.80 \pm 0.04$ versus $A \cup C=0.73 \pm 0.05, P=0.0286$ ) and pineal gland displacement severity $(A \cup C=0.80 \pm 0.05$ versus AUC $=0.74 \pm 0.05, P=0.0306$ ) in patients with midline shift $<4 \mathrm{~mm}$ due to $\mathrm{SSICH}$.

3. The FOUR score is statistically more associated with septum pellucidum displacement $(\mathrm{R} 95 \% \mathrm{Cl}=-0.65(-0.54$; $-0.74), P<0.0001$ versus $-0.42(-0.27 ;-0.54), P<0.0001$ for the GCS score, $P=0.0071)$ and pineal gland displacement (R $95 \% \mathrm{Cl}=-0.65(-0.54 ;-0.71), P<0.0001$ versus -0.45 $(-0.31 ;-0.57), P<0.0001$ for the GCS score, $P=0.017)$.

The perspective for the further scientific research is the assessment of the FOUR score prognostic value in patients with $\mathrm{SSICH}$.

\section{Funding}

The study is funded as a part of scientific research work at Zaporizhzhia State Medical University “Optimization of the diagnostic, treatment and rehabilitation approaches in patients with acute and chronic cerebral bloodflow violations", number of state registration 0113 U000798 (2013-2017).

Conflicts of interest: author has no conflict of interest to declare. Конфлікт інтересів: віАсутній. 
Information about author:

Kuznietsov A. A., MD, PhD, Associate Professor of the Department of Nervous Diseases, Zaporizhzhia State Medical University, Ukraine.

\section{Відомості про автора:}

Кузнєцов А. А., канА. меА. наук, Аоцент каф. нервових хвороб, Запорізький Аержавний меАичний університет, Україна.

\section{Сведения об авторе:}

Кузнецов А. А., канА. меА. наук, Аоцент каф. нервных болезней, Запорожский государственный меАицинский университет, Украина.

Надійшла Ао реАакції / Received: 26.09.2018

Після Аоопрацювання / Revised: 03.10.2018

Прийнято АО Аруку / Accepted: 15.10.2018

\section{References}

[1] Baratloo, A., Shokravi, M., Safari, S., \& Aziz, A. K. (2016). Predictive Value of Glasgow Coma Score and Full Outline of Unresponsiveness Score on the Outcome of Multiple Trauma Patients. Arch Iran Med, 19(3), 215-220. doi: 0161903/AlM.0011.

[2] Bordini, A. L., Luiz, T. F., Fernandes, M., Arruda, W. O., \& Teive, H. A. (2010). Coma scales: a historical review. Arq Neuropsiquiatr, 68(6), 930-937. doi: 10.1590/S0004-282X2010000600019.

[3] Braksick, S. A., Hemphill, J. C., Mandrekar, J., Wijdicks, E. F. M., \& Fugate, J. E. (2018). Application of the FOUR Score in Intracerebral Hemorrhage Risk Analysis. J Stroke Cerebrovasc Dis, 27(6), 15651569. doi: 10.1016/j.jstrokecerebrovasdis.2018.01.008.

[4] Bruno, M. A., Ledoux, D., Lambermont, B., Damas, F., Schnakers, C. Vanhaudenhuyse, A., et al. (2011). Comparison of the Full Outline of UnResponsiveness and Glasgow Liege Scale/Glasgow Coma Scale in an intensive care unit population. Neurocrit Care, 15(3), 447-453. doi: 10.1007/s12028-011-9547-2.

[5] Fischer, M., Rüegg, S., Czaplinski, A., Strohmeier, M., Lehmann, A., Tschan, F., et al. (2010). Inter-rater reliability of the Full Outline of UnResponsiveness score and the Glasgow Coma Scale in critically ill patients: a prospective observational study. Crit Care, 14(2), R64. doi: $10.1186 / c c 8963$

[6] Gorii, M. A., Gorii, A. M. \& Hosseini, S. H. (2015). Which score should be used in intubated patients' Glasgow coma scale or full outline of unresponsiveness? Int J Appl Basic Med Res, 5(2), 92-95. doi: 10.4103/2229-516X.157152

[7] Hu, Y., Wang, C., Yan, X., Fu, H., \& Wang, K. (2017). Prediction of conscious awareness recovery after severe acute ischemic stroke. $J$ Neurol Sci, 383, 128-134. doi: 10.1016/.j.jns.2017.10.034

[8] Jalali, R., \& Rezaei, M. (2014). A comparison of the glasgow coma scale score with full outline of unresponsiveness scale to predict patients' traumatic brain injury outcomes in intensive care units. Crit Care Res Pract, 2014, 289803. doi: 10.1155/2014/289803.

[9] Kocak, Y., Ozturk, S., Ege, F., \& Ekmekci, H. (2012). A useful new coma scale in acute stroke patients: FOUR score. Anaesth Intensive Care, 40(1), 131-136.

[10] Kramer, A. A., Wijdicks, E. F., Snavely, V. L., Dunivan, J. R., Naranjo, L. L., Bible, S., et al. (2012). A multicenter prospective study of interobserver agreement using the Full Outline of Unresponsiveness score coma scale in the intensive care unit. Crit Care Med, 40(9), 2671-2676. doi: 10.1097/CCM.0b013e318258fd88.

[11] Okasha, A. S., Fayed, A. M., \& Saleh, A. S. (2014). The FOUR score predicts mortality, endotracheal intubation and ICU length of stay after traumatic brain injury. Neurocrit Care, 21(3), 496-504. doi: 10.1007/ s12028-014-9995-6.

[12] Spina, S., Marzorati, C., Vargiolu, A., Magni, F., Riva, M., Rota, M. et al. (2017). Intracerebral hemorrhage in intensive care unit: early prognostication fallacies. A single center retrospective study. Minerva Anestesiol., 84(5), 572-581. doi: 10.23736/S0375-9393.17.12225-X.

[13] Temiz, N. C., Kose, G., Tehli, O., Acikel, C., \& Hatipoglu, S (2018). A Comparison Between the Effectiveness of Full Outline of Unresponsiveness and Glasgow Coma Score at Neurosurgica Intensive Care Unit Patients. Turk Neurosurg, 28(2), 248-250. doi: 10.5137/1019-5149.JTN.19504-16.0

[14] Wijdicks, E. F., Kramer, A. A., Rohs, T. Jr., Hanna, S., Sadaka, F., O'Brien, J., et al. (2015). Comparison of the Full Outline of UnResponsiveness score and the Glasgow Coma Scale in predicting mortality in critically ill patients. Crit Care Med, 43(2), 439-444. doi: $10.1097 /$ CCM. 0000000000000707
[15] Wijdicks, E. F. (2006). Clinical scales for comatose patients: the Glasgow Coma Scale in historical context and the new FOUR Score. Rev Neurol Dis., 3(3), 109-117.

[16] Wijdicks, E. F., Bamlet, W. R., Maramattom, B. V., Manno, E. M., \& McClelland, R. L. (2005). Validation of a new coma scale: The FOUR score. Ann Neurol, 58(4), 585-593. doi: 10.1002/ana.20611.

[17] Zweig, M. H., \& Campbell, G. (1993). Receiver-operating characteristic (ROC) plots: a fundamental evaluation tool in clinical medicine. Clin Chem, 39(4), 561-577. 